\title{
Control of Exocytosis by Synaptotagmins and Otoferlin in Auditory Hair Cells
}

\author{
Maryline Beurg, ${ }^{1}$ Nicolas Michalski, ${ }^{2}$ Saaid Safieddine, ${ }^{3}$ Yohan Bouleau, ${ }^{1}$ Ralf Schneggenburger, ${ }^{2}$ Edwin R. Chapman, \\ Christine Petit, ${ }^{3,5}$ and Didier Dulon ${ }^{1}$ \\ ${ }^{1}$ Equipe Neurophysiologie de la Synapse Auditive, Institut National de la Santé et de la Recherche Médicale (Inserm), Unité Mixte de Récherche Scientifique \\ (UMRS) 587, Université Victor Segalen and Institut des Neurosciences de Bordeaux, Centre Hospitalier Universitaire Pellegrin, 33076 Bordeaux, France, \\ ${ }^{2}$ Laboratory of Synaptic Mechanisms, Brain-Mind Institute, Ecole Polytechnique Fédérale de Lausanne, 1015 Lausanne, Switzerland, ${ }^{3}$ Unité de Génétique et \\ Physiologie de l'Audition, Inserm UMRS 587, Institut Pasteur et Université Pierre et Marie Curie, 75724 Paris, France, ${ }^{4}$ Howard Hughes Medical Institute \\ and Department of Physiology, University of Wisconsin, Madison, Wisconsin 53706, and ${ }^{5}$ Collège de France, 75005 Paris, France
}

In pre-hearing mice, vesicle exocytosis at cochlear inner hair cell (IHC) ribbon synapses is triggered by spontaneous $\mathrm{Ca}^{2+}$ spikes. At the onset of hearing, IHC exocytosis is then exclusively driven by graded potentials, and is characterized by higher $\mathrm{Ca}^{2+}$ efficiency and improved synchronization of vesicular release. The molecular players involved in this transition are still unknown. Here we addressed the involvement of synaptotagmins and otoferlin as putative $\mathrm{Ca}^{2+}$ sensors in IHC exocytosis during postnatal maturation of the cochlea. Using cell capacitance measurements, we showed that $\mathrm{Ca}^{2+}$-evoked exocytosis in mouse IHCs switches from an otoferlin-independent to an otoferlin-dependent mechanism at postnatal day 4. During this early exocytotic period, several synaptotagmins (Syts), including Syt1, Syt2 and Syt7, were detected in IHCs. The exocytotic response as well as the release of the readily releasable vesicle pool (RRP) was, however, unchanged in newborn mutant mice lacking Syt1, Syt2 or Syt7 $\left(S y t 1^{-1-}, S y t 2^{-1-}\right.$ and Syt7 $7^{-1-}$ mice). We only found a defect in RRP recovery in Syt1 ${ }^{-1-}$ mice which was apparent as a strongly reduced response to repetitive stimulations. In post-hearing Syt2 ${ }^{-1-}$ and $S y t 7^{-1-}$ mutant mice, IHC synaptic exocytosis was unaffected. The transient expression of Syt1 and Syt2, which were no longer detected in IHCs after the onset of hearing, indicates that these two most common $\mathrm{Ca}^{2+}$-sensors in CNS synapses are not involved in mature IHCs. We suggest that otoferlin underlies highly efficient $\mathrm{Ca}^{2+}$-dependent membrane-membrane fusion, a process likely essential to increase the probability and synchrony of vesicle fusion events at the mature IHC ribbon synapse.

\section{Introduction}

Before the onset of hearing, cochlear inner hair cells (IHCs) exhibit spontaneous $\mathrm{Ca}^{2+}$ spiking activity that triggers synaptic exocytosis (Kros et al., 1998; Beutner et al., 2001; Marcotti et al., 2003; Tritsch and Bergles, 2010) and postsynaptic trains of action potentials (APs) in cochlear ganglion neurons (Lippe, 1994; Jones et al., 2007; Tritsch et al., 2007). In mature IHCs, exocytosis is then driven by sound-evoked fast graded receptor potentials. In both immature and mature IHCs, neurotransmitter release is triggered by $\mathrm{Ca}^{2+}$ influx flowing through L-type $\mathrm{Ca}^{2+}$ channels (Moser and Beutner, 2000; Glowatzki and Fuchs, 2002; Brandt et

Received May 18, 2010; revised July 22, 2010; accepted July 30, 2010.

This work was supported by grants from the European Commission FP6 Integrated Project EuroHear (LSHG-CT2004-512063), the French National Research Agency (ANR-07-Neuroscience), Louis-Jeantet for Medecine Foundation (C.P.), the Fondation Voir \& Entendre, and National Institutes of Health Grant R01-MH06186 (E.R.C.). E.R.C. is an Investigator of the Howard Hughes Medical Institute. N.M. was supported by the EMBO (European Molecular Biology Organization) Long Term Fellowship (ALTF 724-2008). We thank Norma Andrews at the University of Maryland for providing us with the Syt7-null mice, and Roberto Adachi and Thomas C. Südhof for providing us with Syt2-null mice. We also thank Robert Fettiplace for his scientific support and advice, Huisheng Liu for his help on Syt1 and Syt7 projects, Jean-Pierre Hardelin for critical reading of the manuscript, and Lance Rodenkirch and Mireille Montcouquiol for their help with confocal microscopy.

Correspondence should be addressed to any of the following: Maryline Bordeaux, E-mail: maryline.beurg@ inserm.fr, Christine Petit, E-mail: cpetit@pasteur.fr, or Didier Dulon, E-mail: didier.dulon@inserm.fr at the above addresses.

DOI:10.1523/JNEUROSCI.2528-10.2010

Copyright $\odot 2010$ the authors $\quad 0270-6474 / 10 / 3013281-10 \$ 15.00 / 0$ al., 2003), and the efficiency of brief $\mathrm{Ca}^{2+}$ currents in evoking release increases with cell maturation (Beutner and Moser, 2001; Johnson et al., 2005). Synchronization of the multivesicular release process (Glowatzki and Fuchs, 2002) also improves with IHC maturation (Grant et al., 2010), which suggests that concomitant, as yet poorly understood changes take place in the IHC synaptic machinery.

Like in most neurosecretory cells, synaptic exocytosis in IHCs is thought to involve interactions of SNARE (soluble $N$-ethylmaleimide-sensitive-factor attachment protein receptor) complex proteins attached to synaptic vesicles (synaptobrevin) with the target plasma membrane (SNAP-25 and syntaxin 1) (Safieddine and Wenthold, 1999). Synaptotagmins (Syts), a large family of transmembrane proteins containing tandem $\mathrm{Ca}^{2+}$ binding C2-domains, confer $\mathrm{Ca}^{2+}$ sensitivity to SNAREdependent vesicle fusion in the CNS (Chapman, 2008), but their implication in IHC synaptic exocytosis is still unclear. Indeed, the transcripts encoding Syt1 and Syt2, the major $\mathrm{Ca}^{2+}$ sensors for fast synchronized transmitter release in central neurons (Geppert et al., 1994; Sun et al., 2007), have not been detected in mature IHCs (Safieddine and Wenthold, 1999). Therefore, otoferlin, a six C2-domain transmembrane protein (Yasunaga et al., 1999), has been proposed as a major $\mathrm{Ca}^{2+}$ sensor required for $\mathrm{Ca}^{2+}$ evoked exocytosis in IHCs (Roux et al., 2006). 
The synaptic active zone of IHCs has been proposed to be organized in independent $\mathrm{Ca}^{2+}$ nanodomains, where the activity of one or few $\mathrm{Ca}^{2+}$ channels is sufficient to activate release of a nearby vesicle (Brandt et al., 2005), allowing the synapse to function in a linear regime (Johnson et al., 2005; Keen and Hudspeth, 2006; Goutman and Glowatzki, 2007). Recently, Syt4, which does not bind $\mathrm{Ca}^{2+}$ and is not established as a $\mathrm{Ca}^{2+}$ sensor (von Poser et al., 1997), has been shown to be required for the linear $\mathrm{Ca}^{2+}$ dependence of exocytosis (Johnson et al., 2010). Notably, this latter study also reported the expression of Syt1 and Syt2 in immature and mature IHCs, respectively, but the functional implication of these findings has not yet been investigated. To clarify the respective roles of these putative $\mathrm{Ca}^{2+}$ sensors at the IHC ribbon synapse along the course of cochlear maturation, we studied their expression and analyzed $\mathrm{Ca}^{2+}$-dependent exocytosis in

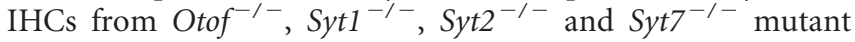
mice that lack otoferlin, Syt1, Syt2 and Syt7, respectively (Geppert et al., 1994; Roux et al., 2006; Sun et al., 2007).

\section{Materials and Methods}

\section{Electrophysiological recordings}

Experiments were performed on mice, both male and female, obtained by interbreeding of heterozygous mutant mice $\left(\mathrm{Otof}^{+/-}\right.$or Syt ${ }^{+/-}$animals) and genotyped using PCR. Recordings and analyses were performed in blind before knowing the genotype of the mice. All experiments were performed in accordance with the European Communities Council Directive of November 24, 1986 (86/609/EEC). All cares were taken to minimize animals' pain. Whole-cell recordings were performed on excised apical coils of organs of Corti as previously described (Beurg et al., 2008). Dissections were done in a solution containing the following (in $\mathrm{mm}$ ): $135 \mathrm{NaCl}, 5.8 \mathrm{KCl}, 1.3 \mathrm{CaCl}_{2}$, $0.9 \mathrm{MgCl}_{2}, 0.7 \mathrm{NaH}_{2} \mathrm{PO}_{4}, 5.6$ glucose, $2 \mathrm{Na}$-pyruvate, 10 HEPES, pH 7.4.

Borosilicate patch electrodes (World Precision Instruments) were coated with ski wax (SWIX) to minimize electrode capacitance. Pipette resistances in solution were 2-3 $\mathrm{M} \Omega$. Experiments were done at room temperature $\left(20-22^{\circ} \mathrm{C}\right)$.

Recordings in otoferlin-null mice were acquired with an Optopatch amplifier (Cairn Research Ltd) digitized using pClamp10 software and a Digidata 1320 A (Molecular Devices). Analysis was performed using Clampfit (Molecular Devices) and Igor software (Wavemetrics). Record-

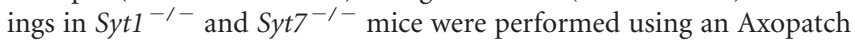
200A digitized using JClamp (SciSoft) and a Micro1401 Interface (Cambridge Electronic Design). Recordings in Syt2 ${ }^{-1-}$ mice were performed using an EPC-10 patch-clamp amplifier and the Patchmaster software (HEKA). Current recordings were corrected for linear leak conductance measured near $-80 \mathrm{mV}$. All voltages were corrected for liquid junction potential. For cell capacitance experiments, extracellular solution contained the following (in mM): $115 \mathrm{NaCl}, 6 \mathrm{KCl}, 5 \mathrm{CaCl}_{2}, 1 \mathrm{MgCl}_{2}, 30 \mathrm{TEA}$, $2 \mathrm{Na}$ pyruvate, 8 glucose, $10 \mathrm{Na}$-HEPES, pH 7.4. Tetrodotoxin $(1 \mu \mathrm{M})$ and apamin $(1 \mu \mathrm{M})$ were added to the extracellular solution. Pipette solution for cell membrane capacitance $\left(C_{\mathrm{m}}\right)$ experiments contained the following (in mM): $142 \mathrm{CsCl}, 1.5 \mathrm{MgCl}_{2}, 5$ TEA, 1 EGTA, 5 creatine phosphate, 10 Cs-HEPES, pH 7.2. ATP was omitted to minimize activation of purinergic receptors, reported in IHCs after P4 (Tritsch and Bergles, 2010). No noticeable difference was observed in changes in cell membrane capacitance $\left(\Delta C_{\mathrm{m}}\right)$ measurements performed in the presence or absence of the nucleotide (data not shown). When EGTA was increased to $5 \mathrm{~mm}$, osmolarity was kept constant to $290 \mathrm{mOsm} / \mathrm{L}$ by reduction of $\mathrm{CsCl}$. For experiments in Syt2 $2^{-1-}$ mice, dissections were done in a solution containing the following (in $\mathrm{mM}$ ): $143 \mathrm{NaCl}, 6 \mathrm{KCl}, 1.3 \mathrm{CaCl}_{2}, 0.9$ $\mathrm{MgCl}_{2}, 0.7 \mathrm{NaH}_{2} \mathrm{PO}_{4}, 8$ glucose, 2 Na-pyruvate, $10 \mathrm{Na}$-HEPES, pH 7.4. Extracellular recording solution was (in $\mathrm{mM}$ ): $119 \mathrm{NaCl}, 6 \mathrm{KCl}, 5 \mathrm{CaCl}_{2}$, $1 \mathrm{MgCl}_{2}, 27$ TEA, 2 Na pyruvate, 8 glucose, 10 Na-HEPES, pH 7.4. Tetrodotoxin $(1 \mu \mathrm{M})$ and apamin $(1 \mu \mathrm{M})$ were also added to the extracellular solution for $C_{\mathrm{m}}$ measurements. Pipette solution for $C_{\mathrm{m}}$ experiments in Syt2 $2^{-\prime}$ mice contained the following (in $\mathrm{mM}$ ): 140 Cs-gluconate, 4 MgATP, $0.3 \mathrm{Na}_{2}$ GTP,20 TEA-Cl, 0.5 EGTA, 5 creatine phosphate, 10 HEPES $\mathrm{pH} 7.2$.
For action potential and afferent fiber recordings, the internal solution contained the following (in mM): $140 \mathrm{KCl}, 3.5 \mathrm{MgCl}_{2}, 0.1 \mathrm{CaCl}_{2}, 5 \mathrm{EGTA}$, HEPES 5, pH 7.2.

Capacitance measurement. Changes in cell membrane capacitance $\left(\Delta C_{\mathrm{m}}\right)$ were used to monitor fusion of synaptic vesicles during exocytosis. $C_{\mathrm{m}}$ was measured according to the Lindau-Neher technique (Lindau and Neher, 1988), using the tracking circuitry of the Optopatch (experiments on otoferlin-null mice) or implemented in the JClamp (Scisoft, New Haven, CT) (Syt1-null or Syt7-null mice recordings), or the Patchmaster softwares (Syt2-null mice). A $20 \mathrm{mV}$ amplitude sine wave from a holding potential of $-80 \mathrm{mV}$ was used; for recording of Syt2-null mice, the sine wave had an amplitude of $30 \mathrm{mV}$ from a holding potential of -90 $\mathrm{mV}$. The resulting maximal depolarizations to $\sim-60 \mathrm{mV}$ were sufficiently small to avoid activation of $\mathrm{Ca}^{2+}$ current $\left(I_{\mathrm{Ca}}\right)$. The command sine wave $(781.3-1600 \mathrm{~Hz})$ was blanked during the duration of the voltage step and resumed immediately upon repolarization to capture the capacitance before and after the pulse. $\Delta C_{\mathrm{m}}$ was estimated as the mean $C_{\mathrm{m}}$ measured $150 \mathrm{~ms}$ after the end of the voltage step (to discard capacitance changes due to $I_{\mathrm{Ca}}$ tail currents) over a period of $50 \mathrm{~ms}$ and the prepulse $C_{\mathrm{m}}$ averaged over $50 \mathrm{~ms}$. Only cells with stable series resistance below $10 \mathrm{M} \Omega$ (uncompensated) were included in the study.

Afferent fiber recordings. EPSCs were recorded using the whole-cell patch-clamp technique, digitized at $50 \mathrm{kHz}$, and low pass filtered at 5-10 $\mathrm{kHz}$. Patch pipettes had a resistance of $\sim 10 \mathrm{M} \Omega$.

Curve fitting and statistical analyses. Curve fitting and analysis were done using Igor Pro (WaveMetrics). The criterion for statistical significance was chosen to be $p<0.05$ using unpaired Student's $t$ test. Variability is reported as mean \pm SEM.

\section{Single-cell reverse transcription PCR}

Inner hair cells were collected from excised organs of Corti (of P1 and P7 mice). Single-cell reverse transcriptase (RT)-PCR was done as previously described (Michalski et al., 2007). Synthesis of cDNA was performed using the SuperScript II Reverse Transcriptase kit (Invitrogen). For each cell, we used the extracellular fluid as a negative control. A multiplex nested PCR was performed using specific primers for the tested synaptotagmin (Syt) transcripts (see supplemental Table, available at www.jneurosci.org as supplemental material, for primer sequence) and for two control transcripts, namely myosin VIIa [Myo7A, expressed in both outer hair cells (OHCs) and IHCs] and prestin (only in OHCs) (same primers reported by Michalski et al., 2007). PCR products were sequenced to confirm their specificity. The PCR consisted of 20 amplification cycles $\left(40 \mathrm{~s}\right.$ at $95^{\circ} \mathrm{C}, 45 \mathrm{~s}$ at $58^{\circ} \mathrm{C}$, and $50 \mathrm{~s}$ at $72^{\circ} \mathrm{C}$ ). Amplified DNA fragments had a molecular weight ranging between 300 and $500 \mathrm{bp}$. The nested PCR was performed in a $25 \mu \mathrm{l}$ mix containing $2 \mu \mathrm{l}$ of the first PCR mix and only one set of inner primers at a time through 35 cycles $\left(40 \mathrm{~s}\right.$ at $95^{\circ} \mathrm{C}, 45 \mathrm{~s}$ at $58^{\circ} \mathrm{C}$, and $50 \mathrm{~s}$ at $\left.72^{\circ} \mathrm{C}\right)$.

Twenty IHCs were collected for each developmental stage. Only IHCs that showed the myosin VIIa-positive and prestin-negative expression profiles were taken into account for result analysis $(n=13)$. The number of Syt-positive cells was then counted for each Syt and compared statistically to the number of extracellular fluid control samples $(n=20)$ that abnormally scored positive for the presence of cDNA amplification, using the $\chi^{2}$ test (with Yates correction for small samples) to check for significance $(p<0.05)$.

\section{Whole-mount immunohistochemistry}

Cochleae were fixed with $4 \%$ paraformaldehyde in PBS for $1 \mathrm{~h}$ at $4^{\circ} \mathrm{C}$, and the external bone was removed. The organ of Corti was isolated and the tectorial membrane was removed. The tissue samples were permeabilized with $0.3 \%$ Triton X-100 in PBS containing 20\% normal goat serum for $1 \mathrm{~h}$ at room temperature. After PBS washes, they were incubated with the primary antibodies, diluted in PBS containing 10\% goat serum (or horse serum) and $0.1 \%$ Triton X-100, overnight at $4^{\circ} \mathrm{C}$. Omission of the primary antibody was used as a negative control. Primary antibodies were used at the following dilutions: anti-Syt1 (1: 200, rabbit polyclonal, Synaptic Systems; 1:500 mouse monoclonal (C141.1), Synaptic Systems; 1:500 rabbit polyclonal, Abcam), anti-Syt7 (1:200, rabbit polyclonal, Synaptic Systems), anti-Syt2 (znp-1 1:200, mouse monoclonal, ZIRC; or 1:200, rabbit polyclonal against 

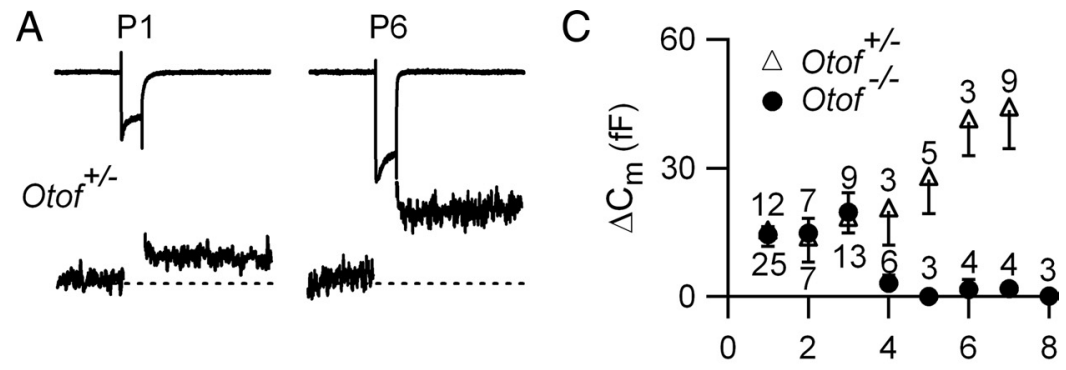

B
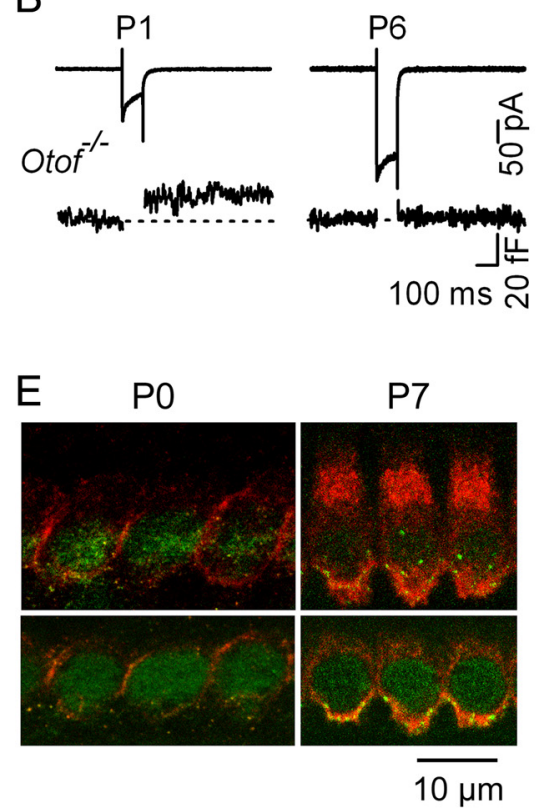
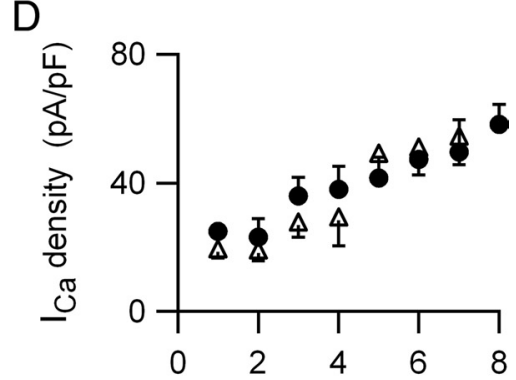

$\mathrm{F}$

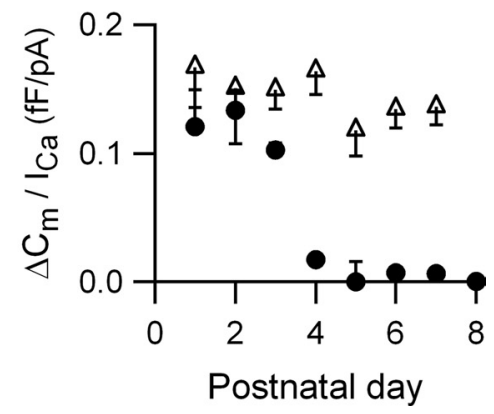

Figure 1. $\mathrm{Ca}^{2+}$-evoked exocytosis in IHCs during early postnatal development: an otoferlin-independent process before $P 4 . \boldsymbol{A}$, $B$, Examples of $I_{\mathrm{Ca}}$ and corresponding $\Delta C_{\mathrm{m}}$ responses in P1 and P6 control and Otof ${ }^{-1-} \mathrm{IHCs}$. Cells were stimulated by a $100 \mathrm{~ms}$ voltage step from a holding potential of $-80 \mathrm{mV}$ to $-10 \mathrm{mV}$. C, $\boldsymbol{D}, \Delta C_{\mathrm{m}}$ response average $(\boldsymbol{C})$ and corresponding $I_{\mathrm{Ca}} \operatorname{density}(\boldsymbol{D})$ from IHCs at different postnatal stages. $\boldsymbol{E}$, Otoferlin (red) and CTBP2 (green) immunolabelings in IHCs from P0 and P7 mice. Note the increase in otoferlin immunoreactivity at P7.,$_{,} \mathrm{Ca}^{2+}$ efficiency $\left(\Delta C_{\mathrm{m}} / I_{\mathrm{Ca}}\right)$ of exocytosis as a function of development for the cells tested in $\boldsymbol{C}$ and $\boldsymbol{D}$.

Syt2, Synaptic Systems), anti-neurofilament NF-200 (1:1000, mouse monoclonal, a gift from Dr. D. Dahl, Harvard Medical School, Boston, MA), antisynaptophysin (1:200 mouse monoclonal, Sigma; 1:200 rabbit polyclonal, Synaptic Systems), anti-CtBP2 (1:200, goat polyclonal, Santa Cruz Biotechnology). Tissue samples were washed in PBS, and incubated with secondary antibodies for $2 \mathrm{~h}$ at room temperature. Dilutions of secondary antibodies were as follows: goat anti-rabbit IgG coupled to Alexa Fluor 488 (1:500); goat anti-mouse IgG antibody conjugated with Cy3 fluorophore (Jackson ImmunoResearch Laboratories); goat anti-mouse IgG coupled to Alexa Fluor 488 (1:500), chicken anti-goat IgG coupled to Alexa Fluor 488 (1:1000). The nuclear dye DAPI was added to aid in hair cell visualization. The samples were analyzed using a confocal laser scanning microscope LSM510 Meta (Zeiss, Pasteur Institute, Imagepole) or a Leica confocal upright microscope (Leica DMR TCS SP2 AOBS, Bordeaux Imaging Center). The images were taken with a step size of $0.4 \mu \mathrm{m}$.

Specificity of anti-Syt antibodies was determined by the lack of residual Syt-immunostaining in the organ of Corti of the respective Syt-null mutant mice. The persistence of the IHCs immunostaining observed in Syt2-null mice when using anti-Syt2 polyclonal antibody (from Synaptic Systems) indicated the nonspecificity of this labeling (data not shown). Therefore, the Syt2 distribution in the organ of Corti was only documented using the znp-1 monoclonal antibody. Similarly, the distribution of Syt7 could not be reliably analyzed since the immunostaining of the organ of Corti obtained with the anti-Syt7 polyclonal antibody (Synaptic Systems) was still detected in Syt $7^{-/-}$mutant mice (data not shown). In contrast, the specificity of the IHC immunolabeling that was observed in wild-type mice using polyclonal anti-Syt1 (Synaptic Systems) and monoclonal anti-Syt2 (ZIRC) antibodies could be established by the lack of staining in the Syt1 ${ }^{-/-}$or Syt2 $2^{-/-} \mathrm{mu}-$ tant mice that lack Syt 1 and Syt2, respectively (supplemental Fig. 2, available at www. jneurosci.org as supplemental material). The same Syt 1 immunostaining was observed in the organ of Corti from wild-type mice using any of the three antibodies directed against this protein (data not shown).

\section{Results}

Exocytosis in IHCs from early postnatal mice is otoferlin independent

Otoferlin is critical for $\mathrm{Ca}^{2+}$-triggered synaptic exocytosis in IHCs from P6 onwards (Roux et al., 2006). However, IHC exocytosis has not been explored at earlier developmental stages. We thus characterized the $\mathrm{Ca}^{2+}$-dependent exocytosis in IHCs from Otof ${ }^{-/-}$mice and control littermates from postnatal days 1-8 (P1P8). To this purpose, we monitored $\Delta C_{\mathrm{m}}$ in response to voltage activation of $I_{\mathrm{Ca}}$. Electrophysiological data obtained from $\mathrm{Otof}^{+/+}$and Otof ${ }^{+/-}$IHCs were pooled and referred to as "controls", after checking that there was no statistical difference between the two groups (unpaired $t$ test, $p<0.01$ ).

In P1 control and Otof ${ }^{-1-}$ IHCs, substantial $\Delta C_{\mathrm{m}}$ responses could be recorded (Fig. $1 A, B$ ). In P1 Otof ${ }^{-/-}$IHCs, the mean $\Delta C_{\mathrm{m}}$ evoked by a $100 \mathrm{~ms}$ voltagestep to $-10 \mathrm{mV}\left(I_{\mathrm{Ca}}\right.$ peak) was $17.5 \pm 1.7$ $\mathrm{fF}(n=25)$, a value similar to that found in control IHCs $(14.9 \pm 3.1 \mathrm{fF}, n=12 ; p=$ 0.12) (Fig. 1C). These $\Delta C_{\mathrm{m}}$ responses were abolished by $50 \mu \mathrm{M}$ nifedipine (data not shown, $n=2$ ), indicating that this otoferlin-independent exocytosis is also triggered by L-type $\mathrm{Ca}^{2+}$ channels. The $\Delta C_{\mathrm{m}}$ responses in Otof ${ }^{-\prime-}$ IHCs dramatically decreased at $\mathrm{P} 4$, and became undetectable from P5 on (Fig. 1C,F), as previously reported (Roux et al., 2006). Notably, a gradual increase of otoferlin immunolabeling in IHCs was observed during the first week of postnatal development: the staining was weak at P0, maximal at P6 (Fig. $1 E$ ) and remained constant thereafter (Roux et al., 2006). In Otof ${ }^{-/-}$IHCs, the biophysical properties of $\mathrm{Ca}^{2+}$ current (kinetics, voltage activation) and developmental increase in $\mathrm{Ca}^{2+}$ channel density were similar to those of control mice (data not shown and Fig. $1 B-D$ ). During the first postnatal week, we observed a parallel increase of the $I_{\mathrm{Ca}}$ density and the triggered membrane capacitance $\left(\Delta C_{\mathrm{m}}\right)$ in control IHCs (Fig. $1 A, C, D)$, while the $\mathrm{Ca}^{2+}$ efficiency of exocytosis, defined here as $\left(\Delta C_{\mathrm{m}} / I_{\mathrm{Ca}}\right)$ remained identical (Fig. $\left.1 F\right)$, in agreement with previous results showing that the $\mathrm{Ca}^{2+}$ efficiency only starts to increase after P6 (Beutner and Moser, 2001; Johnson et al., 2005). $\mathrm{Up}$ to P3, the $\mathrm{Ca}^{2+}$ efficiency of exocytosis in Otof ${ }^{-/-}$IHCs was similar to that in control IHCs (Fig. $1 F$ ).

Spontaneous firing activity (sensitive to nifedipine) was present with similar event frequencies in P1-P3 IHCs from Otof ${ }^{-1-}$ and control mice (supplemental Fig. 1, available at www.jneurosci.org as supplemental material). This spontaneous 
IHC spiking is likely to be at the origin of the EPSCs and spontaneous APs that we recorded in afferent fibers from Otof ${ }^{-/-}$ and control mice, with similar amplitudes and event frequencies (supplemental Fig. 1 , available at www.jneurosci.org as supplemental material). These results suggest that exocytosis triggered by spontaneous APs in P1-P3 IHCs does not require otoferlin either.

We further characterized the otoferlinindependent synaptic exocytosis in early postnatal IHCs by studying the synaptic transfer function, that is, the relationship between $\mathrm{Ca}^{2+}$ entry and exocytosis. The voltage-evoked $\Delta C_{\mathrm{m}}$ responses $(100 \mathrm{~ms}$ step ranging from -60 to $-10 \mathrm{mV}$ ) were plotted against the corresponding $I_{\mathrm{Ca}}$ amplitudes (Fig. $2 \mathrm{~A}, \mathrm{~B}$ ). The $\mathrm{Ca}^{2+}$ dependence of transmitter release in central synapses, notably at the large calyx of Held nerve terminals, is described by a nonlinear model of cooperative $\mathrm{Ca}^{2+}$ binding to the sensor (Schneggenburger and Neher, 2000; Wölfel and Schneggenburger, 2003). Considering that $\mathrm{Ca}^{2+}$-evoked vesicle fusion $\left(\Delta C_{\mathrm{m}}\right)$ in IHCs is also intrinsically cooperative (Beutner et al., 2001), the data were fitted using the equation $\Delta C_{\mathrm{m}}=g$ $\left[I_{\mathrm{Ca}}\right]^{N}$, with $I_{\mathrm{Ca}}$ varying both as a function of open $\mathrm{Ca}^{2+}$ channels (number increasing with depolarization) and $\mathrm{Ca}^{2+}$ flux per channel (the $\mathrm{Ca}^{2+}$ driving force decreasing with depolarization). In IHCs from both control and Otof ${ }^{-1-} \mathrm{P} 1-\mathrm{P} 3$ mice, the synaptic transfer function displayed a mean power $N=1.7 \pm 0.2$ (parameters fitted separately to each cell) (Fig. 2B). Moreover, the otoferlin-independent (P1-P3) and otoferlin-dependent (P7) synaptic transfer functions were similar in the control mice $(N=1.6 \pm 0.5$ for P7 IHCs, $n=7 ; p=0.8$ ) (Fig. $2 C$ ). These results suggest that otoferlin-dependent and otoferlin-independent exocytosis in immature IHCs display comparable $\mathrm{Ca}^{2+}$ dependencies, notably with a similar cooperative index.

We compared the dynamics of vesicle pool depletion in IHCs from Otof ${ }^{-1-}$ and control newborn mice (P1) by using a constant depolarizing step (from -80 to $-10 \mathrm{mV}$ ) of duration increasing from 10 to $3000 \mathrm{~ms}$ (Fig. 2D-F). Both in control and Otof ${ }^{-\prime-}$ mice, data points ( $\Delta C_{\mathrm{m}}$ vs time) were best fitted by two exponentials, suggesting the presence of two vesicular pools: a readily releasable pool (RRP) and a slowly releasable pool (SRP) that may arise from vesicles docked at the active zones and vesicles located further from the $\mathrm{Ca}^{2+}$ channels, respectively. The RRP component of control and Otof ${ }^{-/-}$P1 IHCs, spanning between 10 and $200 \mathrm{~ms}$, was fitted using a single-exponential with time constants $\tau=48$ and $63 \mathrm{~ms}$, and $\Delta C_{\mathrm{m}(\max )}=21 \mathrm{fF}$ and $16 \mathrm{fF}$, respectively (Fig. $2 D$, inset) (not statistically different, with $p=0.5$, in comparing individual cell fit values). Assuming a $\Delta C_{\mathrm{m}}$ of 37 aF per vesicle (Lenzi et al., 1999), RRP sizes were estimated at 562 and 434 vesicles, respectively. For longer stimuli, control and Otof ${ }^{-/-}$P1 IHCs displayed similar SRP Otof $^{-1}$ mice, respectively.
B

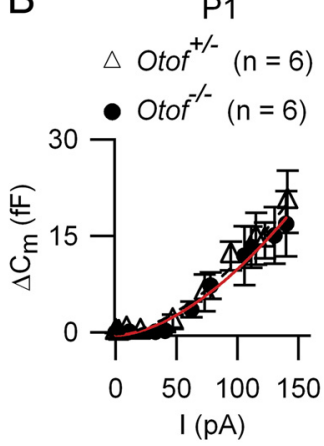

E

P1

$\triangle$ Otof $^{+/-}(\mathrm{n}=6)$

- $\operatorname{Otof}^{-/-}(\mathrm{n}=9)$

EGTA $5 \mathrm{mM}$

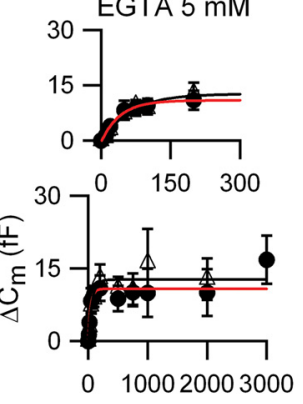

Stimulus duration (ms)
C P7

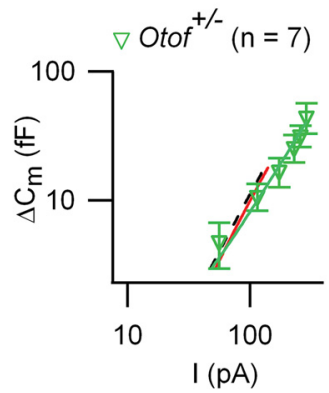

$\mathrm{F}$

P7

$\triangle \operatorname{Otof}^{+/-}(\mathrm{n}=7)$

- $\operatorname{Otof}^{-/-}(n=5)$

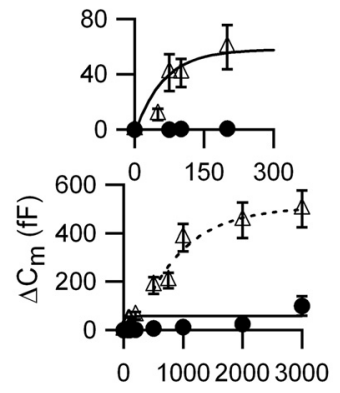

Stimulus duration (ms)

Figure 2. Properties of otoferlin-independent exocytosis in immature IHCs. $A, I_{C_{2}}$-voltage relationship and corresponding $\Delta C_{m}$ in IHCs from control (triangles) and 0 tof ${ }^{-\prime-}$ (circles) P1 mice. $B$, Corresponding synaptic transfer function plot $\left(\Delta C_{\mathrm{m}}\right.$ against $I_{C_{C}}$ (solid line) S.C, Synaptic transfer function for IHCs from P7 control mice (power fit: $N=1.6$ ), plotted on log scales. D, Kinetics of vesicle poo 列 exponential fit of SRP (500-3000 ms). Fit parameters were for RRP, $\tau=48$ and $63 \mathrm{~ms}, \Delta C_{\mathrm{m}(\mathrm{max})}=20.8 \mathrm{fF}$ and $16.2 \mathrm{fF}$, and for exocytosis in the presence of $5 \mathrm{~mm}$ EGTA in P1 IHCs. Note the block of SRP in the presence of EGTA. Fit values were as follows: $\tau=$ $77 \mathrm{~ms}, \Delta C_{\mathrm{m} \text { (max) }}=13 \mathrm{fF}$ (control) and $\tau=45.5 \mathrm{~ms}, \Delta C_{\mathrm{m} \text { (max) }}=11 \mathrm{fF}\left(0\right.$ tof $\left.{ }^{-/-}\right)$. $\boldsymbol{F}$, Absence of fast exocytosis in IHCs from $\Delta C_{\mathrm{m}(\max )}=56 \mathrm{fF}$ for RRP, and $\tau=1000 \mathrm{~ms}, \Delta C_{\mathrm{m}(\max )}=526 \mathrm{fF}$ for SRP. Black and red lines are fits for IHCs from control and

components $\left(\tau=1363\right.$ and $1739 \mathrm{~ms}$, maximal $\Delta C_{\mathrm{m}}=167 \mathrm{fF}$ and $138 \mathrm{fF}$, respectively; Fig. 2D).

In P7 Otof ${ }^{-1-}$ IHCs, we confirmed the absence of vesicular release from the RRP (no $\Delta C_{\mathrm{m}}<500 \mathrm{~ms}$ voltage-steps), but found a residual slow exocytosis for longer stimuli (Fig. $2 F$ ), as previously reported (Roux et al., 2006).

To address the issue of the relative spatial organization of the $\mathrm{Ca}^{2+}$ channels and $\mathrm{Ca}^{2+}$ sensor, we measured the sensitivity of the RRP and SRP components to various intracellular $\mathrm{Ca}^{2+}$ buffer concentrations. Raising the intracellular concentration of the slow $\mathrm{Ca}^{2+}$ buffer EGTA from 1 to $5 \mathrm{~mm}$, a way to limit intracellular $\mathrm{Ca}^{2+}$ spread to within the microdomains, suppressed the SRP-release but not the RRP-release in IHCs from both control and Otof ${ }^{-/-} \mathrm{P} 1$ mice (Fig. 2E). This indicates that $\mathrm{Ca}^{2+}$ channels and non-otoferlin $\mathrm{Ca}^{2+}$ sensors triggering RRP vesicular release work in close vicinity in P1 IHCs. This result also suggests that SRP release results from vesicles located farther from the $\mathrm{Ca}^{2+}$ channels, or, alternatively, might reflect a $\mathrm{Ca}^{2+}$-dependent recovery of the RRP. Furthermore, repetitive exocytosis of the RRP (evoked by a train of $50 \mathrm{~ms}$ depolarizing 


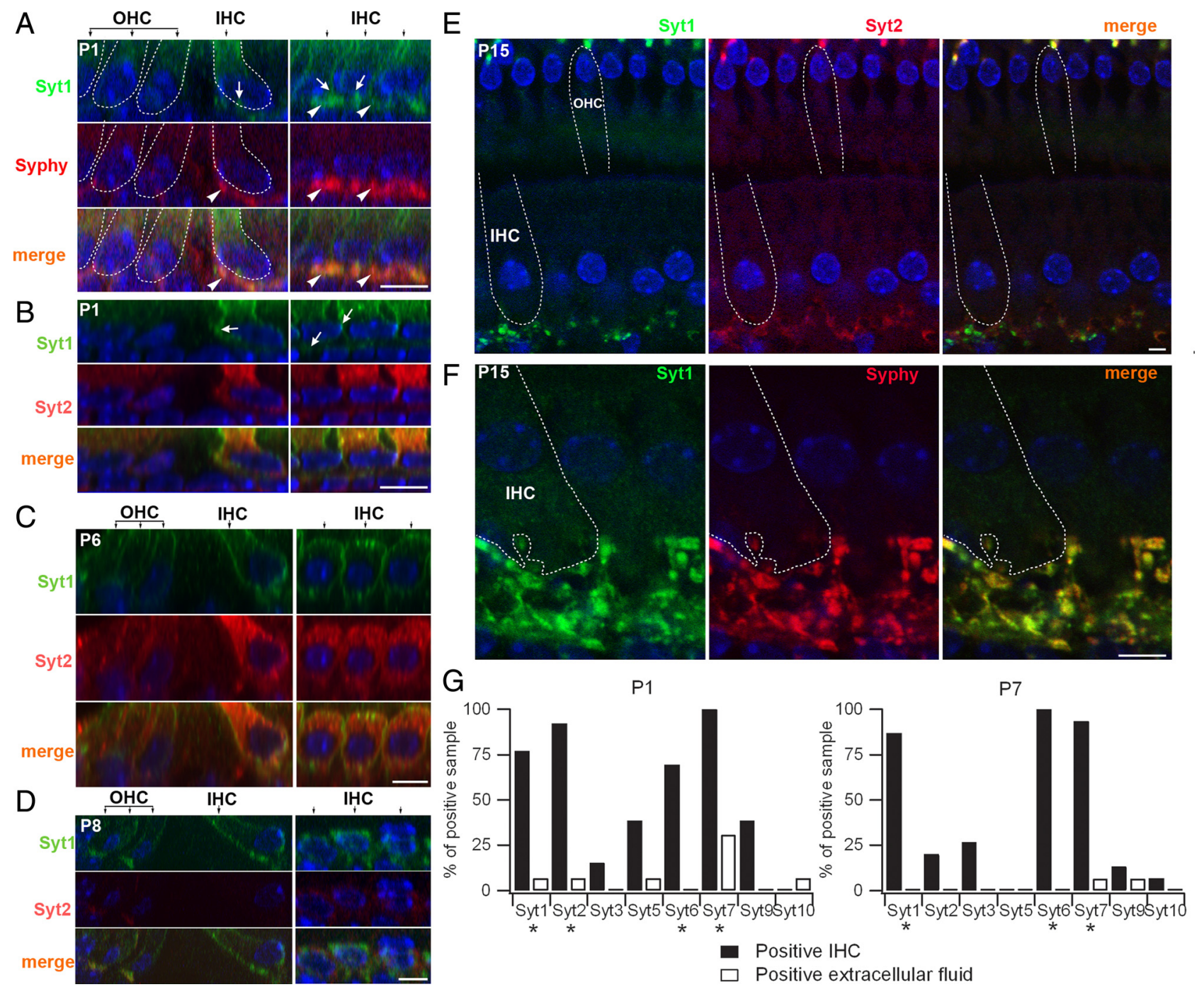

Figure 3. Syts expression in cochlear hair cells. Confocal microscopy images of whole mounts of the organ of Corti at P1, P6, P8, and P15, double-labeled either for Syt1 and synaptophysin (Syphy) $(\boldsymbol{A}, \boldsymbol{F})$, or for Syt1 and Syt2 $(\boldsymbol{B}-\boldsymbol{E})$. DAPI staining (blue) was used to stain cell nuclei. Dashed lines outline IHCs and OHCs (based on the reconstructed $z$-stack, data not shown). $\boldsymbol{A}-\boldsymbol{D}$, Left and right panels are cross-section views in the $x, z$ and $y, z$ plans, respectively. AtP1 and P6, a Syt1 staining can be seen along the membrane of IHCs (arrows in $\boldsymbol{A}$ and $\boldsymbol{B}$, top) and in the terminals of efferent fibers stained for Syphy ( $\boldsymbol{A}$, middle, arrowheads). The merge image ( $\boldsymbol{A}$, bottom) shows an overlapping of Syt1 and Syphy stainings at the efferent fibers below IHCs (arrowheads). No Syphy labeling was seen in IHCS. Syt2 labeling is predominantly cytoplasmic ( $\boldsymbol{B}, \boldsymbol{C}$, middle), compared with that of Syt1, which is mainly located along the basolateral membrane of the cell ( $\boldsymbol{B}, \boldsymbol{C}$, top). At P8, a Syt1 staining is still present in IHCs and $0 \mathrm{HCS}(\boldsymbol{D}$, top), while Syt2 is no longer detected in these cells (D, middle panels). $\boldsymbol{E}$, $\boldsymbol{F}$, At P15, neither Syt2 nor Syt1 are detected in IHCs and $0 \mathrm{HCs}(\boldsymbol{E}$, left and middle). Both proteins are, however, still present in the efferent fibers stained for Syphy ( $\boldsymbol{F}$, middle). Scale bars, $5 \mu \mathrm{m}$. $\boldsymbol{G}$, Single cell RT-PCR was performed in IHCs harvested at P1 and P7. Only IHCs expressing the proper control transcripts (positive for myosin VIIA, and negative for prestin) were computed in the histograms. Data were expressed as a percentage of positive samples [(number of samples containing the Syt transcript/total number of samples tested $\left.\left.)^{*} 100\right)\right]$. Asterisks indicate IHCs with significant positive levels of Syt transcripts $\left(\chi^{2}\right.$ test, $\left.p<0.05\right)$. Transcripts for Syts $1,2,6,7$ and Syts $1,6,7$ were the most abundant Syt transcripts in P1 $(n=13)$ and P7 $(n=13)$ IHCs, respectively. Note the drastic decrease in Syt2 mRNA expression at P7.

steps) was similar in control (see Fig. $4 G$ ) and Otof ${ }^{-/-}$P1 IHCs (data not shown), with an average cumulative $\Delta C_{\mathrm{m}}$ response of $21.8 \pm 0.5 \mathrm{fF}(n=6)$ and $18.4 \pm 4.1 \mathrm{fF}(n=4)$, respectively, which suggests that the recruitment of synaptic vesicles to maintain a constant RRP in P1 IHCs is not affected in the absence of otoferlin. In summary, all parameters of exocytosis tested in P1-P2 Otof ${ }^{-/-}$mice were unchanged compared with their control littermates.

\section{Expression of synaptotagmins in IHCs}

The persistence of $\mathrm{Ca}^{2+}$-dependent exocytosis in IHCs from $\mathrm{P} 0-\mathrm{P} 3 \mathrm{Otof}^{-/-}$mice raises the question of the molecular identity of the $\mathrm{Ca}^{2+}$ sensors involved at early postnatal stages. Since several Syts are regarded as $\mathrm{Ca}^{2+}$ sensors regulating exocytosis in the CNS, we used single-cell RT-PCR to detect Syt transcripts in
IHCs. We investigated the expression of eight different Syts, Syt1, 2, 3, 5, 6, 7, 9 and 10, all known for their $\mathrm{Ca}^{2+}$-binding properties (Südhof, 2002), in P1 and P7 IHCs. Six different Syts were found to be expressed in P1 IHCs, of which Syt 1, 2, 6, and 7 displayed the highest expression levels. In P7 IHCs, Syt1, Syt6 and Syt7 still were strongly expressed, whereas the expression of Syt2 was markedly decreased (Fig. 3G).

These results were further substantiated by immunolabeling experiments and confocal imaging of the organ of Corti before (P1, P6, P8) and after (P15 and P21) the onset of hearing. Wholemount preparations were double-immunostained for Syt 1 or Syt2, and for the synaptic vesicle protein synaptophysin. This latter protein is a marker of lateral efferent presynaptic terminals, that form axodendritic synapses with afferent dendrites below IHCs, and medial efferent synapses contacting OHCs (Gil- 
Loyzaga and Pujol, 1988; Safieddine and Wenthold, 1999). From P1 to P6, Syt1 and Syt2 labelings were present in both IHCs and OHCs (Fig. $3 A-C$ ), but the two proteins displayed different subcellular distributions as shown by double-labeling experiments (Fig. $3 B, C$ ). The strongest Syt1-immunolabeling was observed along the basolateral membrane that lines the IHC presynaptic region (Fig. $3 A, B$ ), whereas the Syt2-immunolabeling was mainly cytoplasmic (Fig. $3 B, C$ ). In addition, Syt1 and Syt2 displayed different temporal profiles in the IHCs, as expected from our single-cell RT-PCR results. The Syt2-immunolabeling was no longer observed in IHCs from P8 onward, while Syt 1 could still be detected up to P10 through all the cochlear spiral (Fig. 3D; supplemental Fig. 3, available at www.jneurosci.org as supplemental material), but vanished at P15 in the IHCs of the cochlear middle turn (Fig. $3 E, F$ ) and at P21 in those of the apical turn (data not shown). Finally, at all stages investigated (from P1 to P21), Syt1 and Syt2 immunolabelings were detected in the efferent, synaptophysin-immunoreactive, nerve fibers (Fig. $3 A-F$; data not shown).

In Otof ${ }^{-/-}$IHCs, Syt1 and Syt2 had the same distributions and developmental patterns, as in control littermates (data not shown). Furthermore, Syt2 was present in P0 Syt1 ${ }^{-/-}$IHCs and Syt1 was present in P0 and P6 Syt2 $2^{-/}$IHCs (data not shown), suggesting that the lack of one $\mathrm{Ca}^{2+}$ sensor does not influence the expression of the other.

\section{Syt1 ${ }^{-/-}$IHCs exhibit a RRP release unchanged but a diminished RRP recovery}

We next assessed the role of Syt 1 in IHC exocytosis by measuring $C_{\mathrm{m}}$ changes in response to $I_{\mathrm{Ca}}$ in P0 Syt1 ${ }^{-1-}$ mice. The short postnatal survival of these mice ( $\sim 24 \mathrm{~h})$ (Geppert et al., 1994) restricted measurements to newborn mice. No morphological anomalies were observed in the IHCs and OHCs of the Syt1 $1^{-1-}$ newborn mice. Indeed, we found presynaptic ribbons and proper innervation contacting the hair cells, with no decrease in the number of cochlear ganglion neurons (Fig. 4A).

In Syt1 ${ }^{-1-}$ P0 IHCs, $I_{\mathrm{Ca}}$-evoked $\Delta C_{\mathrm{m}}$ responses were similar to those in $\mathrm{Syt}^{+/+}$(wild-type) IHCs (Fig. $4 B, C$ ), with a mean amplitude of $25.6 \pm 6.1 \mathrm{fF}(n=11)$ and $28.5 \pm 8.8 \mathrm{fF}(n=11)$, respectively ( $p=0.9$ ) for a $100 \mathrm{~ms}$ voltage-step close to $I_{\mathrm{Ca}}$ peak. The corresponding $I_{\mathrm{Ca}}$ amplitudes were $87 \pm 9 \mathrm{pA}$ and $86 \pm 9 \mathrm{pA}$ $(p=0.8)$ (Fig. 4C). The synaptic transfer function in Syt1 ${ }^{-1-}$ IHCs was evaluated as described above, by plotting $\Delta C_{\mathrm{m}}$ against $I_{\mathrm{Ca}}(100 \mathrm{~ms}$ voltage-step ranging from $-60 \mathrm{mV}$ to $-10 \mathrm{mV}$, from a holding potential of $-80 \mathrm{mV}$ ) (Fig. $4 D$ ). In wild-type and Syt $1^{-/-}$IHCs, the synaptic transfer function was best fitted using $N=2.1 \pm 0.6(n=11)$ and $N=2.0 \pm 0.2(n=10)$, respectively ( $p=0.4$ ), indicating that exocytosis evoked in the absence of Syt1 has an unchanged cooperative index in P0 IHCs. The kinetics of RRP exocytosis $(-10 \mathrm{mV}$ voltage-steps of various durations) were also similar in $S y t 1^{-/-}$mice and control littermates $(\tau=60 \pm 20 \mathrm{~ms}$ and $65 \pm 14 \mathrm{~ms}$, respectively; $p=0.8$; Fig. $4 E)$. This suggested that release from the RRP was unchanged in newborn Syt1 $1^{-\prime-}$ mice.

We observed, however, that depolarizing stimuli had to be separated by at least $1 \mathrm{~min}$ intervals to trigger reproducible $\Delta C_{\mathrm{m}}$ responses in Syt1 ${ }^{-\prime-}$ IHCs. This long time requirement after each $\mathrm{Ca}^{2+}$ stimulation suggested that the recovery of RRP vesicles might be affected in Syt1 ${ }^{-/-}$IHCs. To further investigate the vesicle recruitment and refilling of the RRP, we stimulated IHCs with a train of brief $(50 \mathrm{~ms}$ ) voltage steps spaced by $100 \mathrm{~ms}$ at the holding potential of $-80 \mathrm{mV}$, during which sine wave for $C_{\mathrm{m}}$ measurements was applied (Fig. $4 F$, top). In wild-type mice, a 50
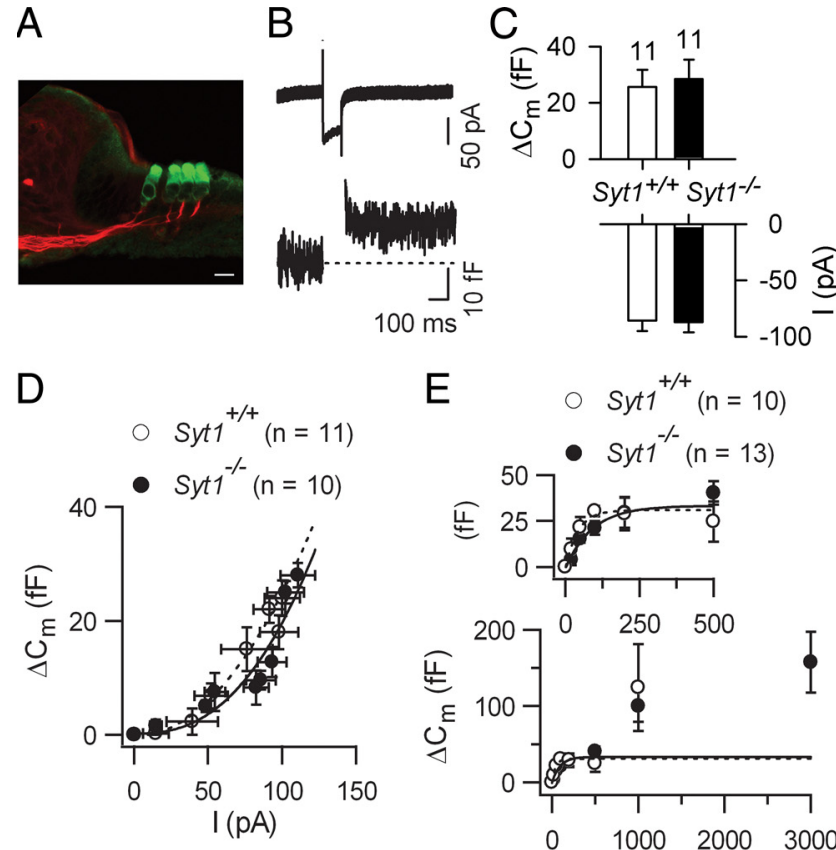

$\mathrm{E}$

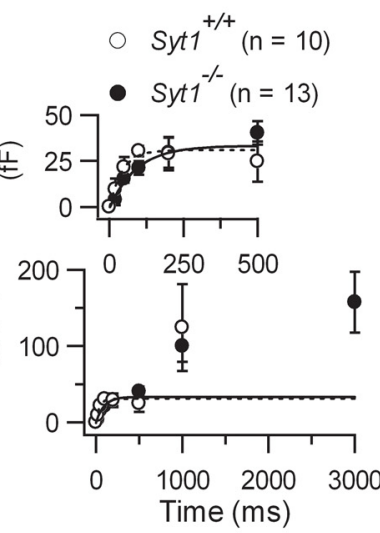

\section{$\mathrm{F}$}

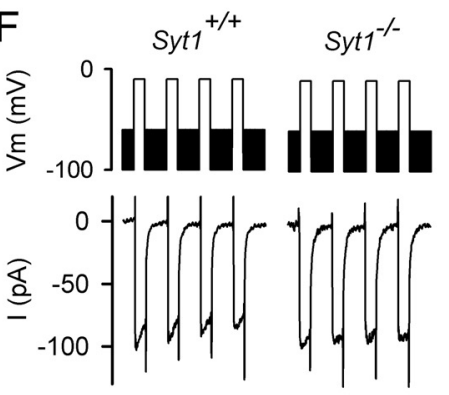

G
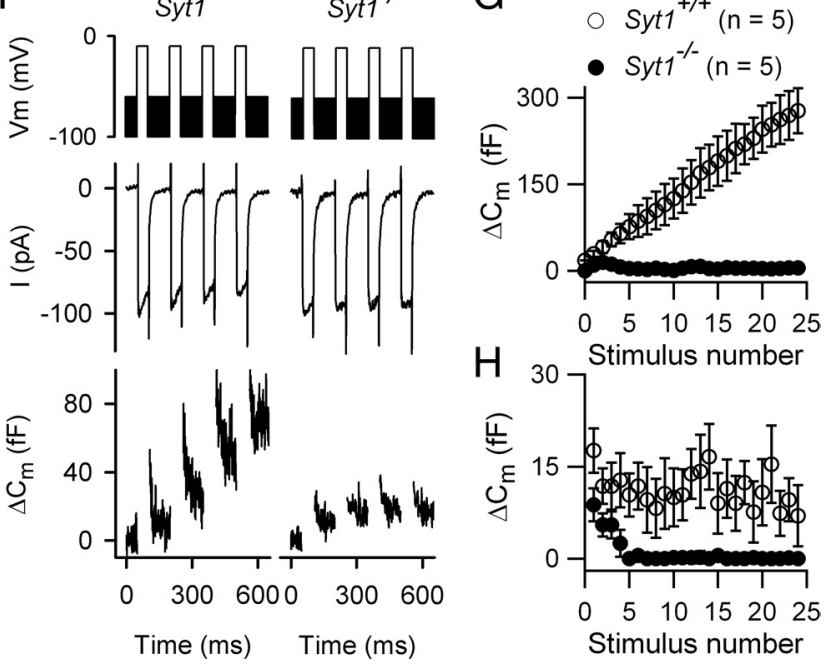

Figure 4. $\mathrm{Ca}^{2+}$-dependent exocytosis in IHCs from Syt $7^{-/-}$newborn mice. $A$, The organ of Corti of Syt $1^{-/-}$PO mice has a normal arrangement of hair cells (green, anti myosin-VIIA labeling) and afferent nerve fibers (red, neurofilament labeling). Scale bar, $10 \mu \mathrm{m} . \boldsymbol{B}$, Example of $\mathrm{I}_{\mathrm{Ca}}$ with its corresponding $\Delta C_{\mathrm{m}}$ response in an $\mathrm{IHC}$ from a Syt $1^{-1-} \mathrm{PO}$ mouse. $C$, Histograms showing the mean $I_{\mathrm{Ca}}$ peak amplitude and its corresponding $\Delta C_{\mathrm{m}}$ for Syt $1{ }^{-/-}$and Syt $1^{+/+}$ IHCs (100 ms voltage step to $-10 \mathrm{mV})$. D, Average $\Delta C_{\mathrm{m}}$ plotted against $I_{\text {Ca }}$ elicited by $100 \mathrm{~ms}$ voltage steps ranging from -60 to $-10 \mathrm{mV}$ (in $5 \mathrm{mV}$ increments). Lines correspond to a power function fit with $N=2.0$ and 2.1 in Syt $1^{+/+}$(dashed line) and Syt $1^{-/-}$(solid line) IHCs, respectively. $\boldsymbol{E}$, Kinetics of $\mathrm{Ca}^{2+}$-dependent exocytosis. $\Delta C_{\mathrm{m}}$ is plotted against stimulus duration at a constant voltage $(-10 \mathrm{mV})$. Lines are single exponential fits for Syt $1^{-1}$ (solid line) and Syt $1^{+/+}$(dashed line) IHCs. $\boldsymbol{F}-\boldsymbol{H}$, Recruitment of vesicles from the fast synaptic vesicular pool. $I_{\mathrm{Ca}}$ and corresponding $\Delta C_{\mathrm{m}}$ elicited by a train of 25 successive $50 \mathrm{~ms}$ voltage steps to -10 $\mathrm{mV}$, separated by $100 \mathrm{~ms}$ time intervals. $\boldsymbol{F}$, Examples are shown for the first four steps. $\mathbf{G}$, Average cumulative $\Delta C_{\mathrm{m}}$ responses obtained for 25 consecutive voltage steps. $\boldsymbol{H}$, Plot of individual $\Delta C_{\mathrm{m}}$ measured after each voltage step.

ms-depolarizing train evoked a linear increase of the cumulative $\Delta C_{\mathrm{m}}$ values (Fig. $4 F, G$ ), indicating that the RRP was able to be rapidly refilled in-between successive stimuli. In contrast, in Syt $1^{-1-}$ IHCs, the RRP recruitment was affected after the second test pulse, despite a stable $I_{\mathrm{Ca}}$ amplitude (Fig. $4 F, G$ ). The $\Delta C_{\mathrm{m}}$ at 

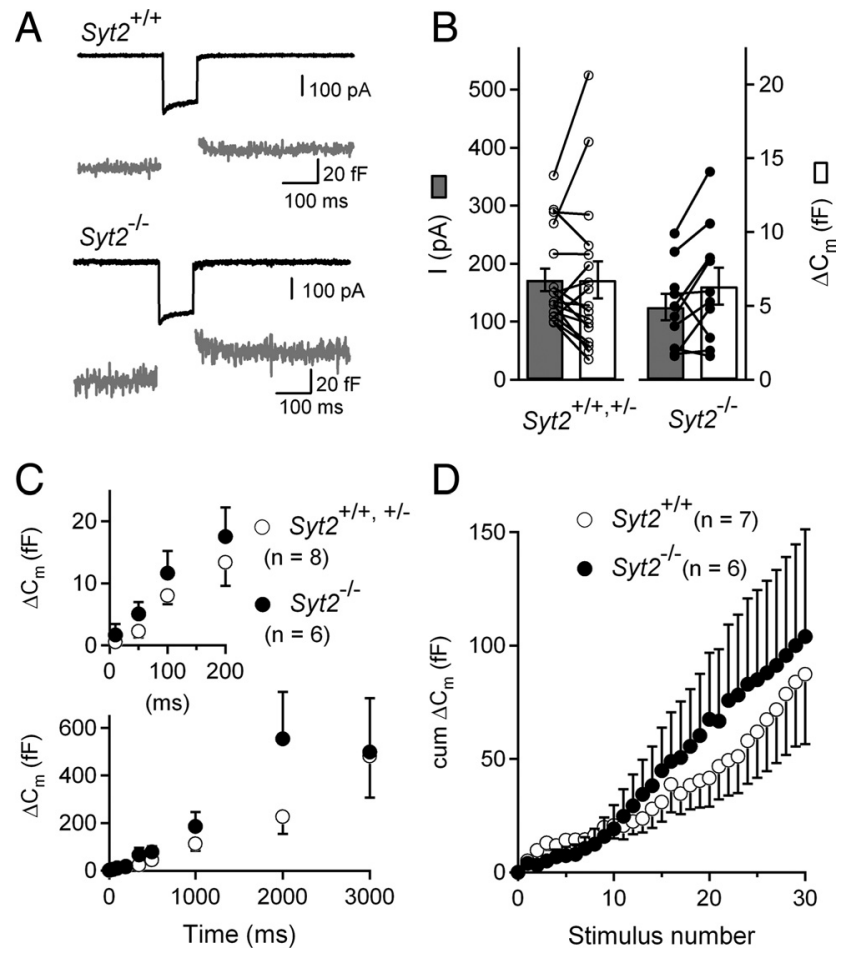

Figure 5. $\mathrm{Ca}^{2+}$-evoked exocytosis in $\mathrm{HHCs}$ from $\mathrm{P} 2-\mathrm{P} 3 \mathrm{Syt}^{-/-}$mice. $\boldsymbol{A}$, Examples of $\mathrm{Ca}^{2+}$-evoked exocytosis in P2-P3 Syt2 ${ }^{+/+}$and Syt2 ${ }^{-/-}$IHCs. Cells were stimulated by a 100 ms voltage step to $-10 \mathrm{mV}$ from a holding potential of $-90 \mathrm{mV}$. $\boldsymbol{B}$, Bar graph of average and individual $I_{\mathrm{Ca}}$ peak amplitudes and their corresponding $\Delta C_{\mathrm{m}}$ values for Syt ${ }^{+/+}(n=17)$ and Syt2 ${ }^{-1-}(n=10)$ IHCs. C, Kinetics of $\mathrm{Ca}^{2+}$-dependent exocytosis. Only cells with large $\Delta C_{\mathrm{m}}$ responses were included for the analysis in this graph. $\boldsymbol{D}$, Average cumulative $\Delta C_{\mathrm{m}}$ responses from P2-P3 Syt2 ${ }^{+/+}$and Syt2 ${ }^{-/-}$IHCs elicited using $50 \mathrm{~ms}$ repetitive voltage steps to -10 $\mathrm{mV}$ (interstep intervals of $100 \mathrm{~ms}$ ).

each step, when plotted against the cumulative number of stimuli, showed a constant value in wild-type IHCs, while this value rapidly decreased to zero after a few steps in Syt1-null IHCs (Fig. $4 H$ ). In summary, these results indicated that in P0 Syt1 ${ }^{-1-}$ IHCs, the RRP release is normal but the process of RRP recovery is strongly affected.

\section{$\mathrm{Ca}^{2+}$-dependent exocytosis is not affected in IHCs from Syt $2^{-/-}$or $S y t 7^{-1-}$ mice}

Syt $2^{-/-}$mice generally survive up to 3 weeks, but exhibit severe motor dysfunction after the second week (Pang et al., 2006). Given the selective expression of Syt 2 in IHCs during the first few postnatal days (Fig. 3), we first studied exocytosis in P2-P3 Syt $2^{-1-}$ IHCs (Fig. 5), but we failed to detect deficits in exocytosis. In Syt $2^{+/+}$or Syt2 $2^{+/-}$control mice, a 100 ms voltage step to $-10 \mathrm{mV}$ evoked a $\mathrm{Ca}^{2+}$ current $\left(I_{\mathrm{Ca}}\right)$ of $172 \pm 19 \mathrm{pA}$, which elicited a $\Delta C_{\mathrm{m}}$ step of $6.8 \pm 1.3 \mathrm{fF}(n=17)$. In Syt2 ${ }^{-/-}$IHCs, a same voltage stimuli elicited an average $\Delta C_{\mathrm{m}}$ response of $6.3 \pm$ $1.3 \mathrm{fF}(n=10)$, which was indistinguishable from the one measured in the control mice $(p>0.5)$. The $\mathrm{Ca}^{2+}$ current was $125 \pm$ $23 \mathrm{pA}(n=10)$; which was slightly, but not significantly smaller than the one measured in control mice $(p=0.13)$. In plots of the exocytotic $\Delta C_{\mathrm{m}}$ response versus the length of the depolarizing pulses, the release kinetics was not substantially modified in Syt $2^{-1-}$ mice compared with control littermates (Fig. 5C). Using a train of brief ( $50 \mathrm{~ms}$ ) voltage steps to $-10 \mathrm{mV}$ (close to peak of $\left.I_{\mathrm{Ca}}\right)$, a sustained vesicular release, similar to controls, could be
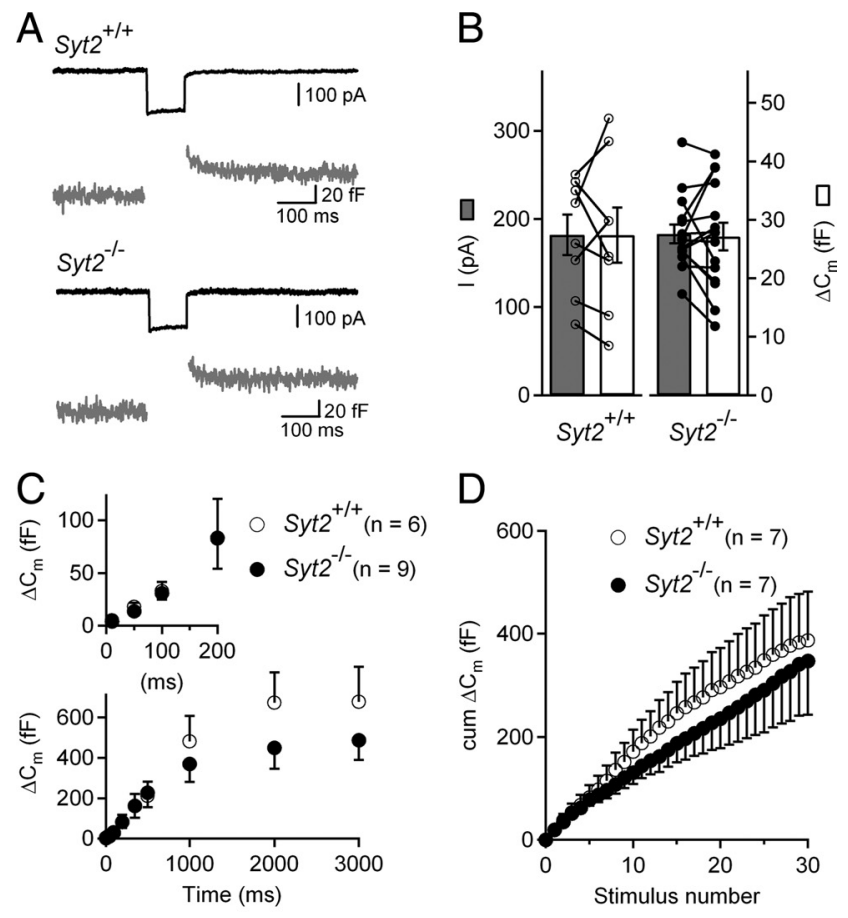

$\mathrm{E}_{\text {syt2 }}{ }^{-1-}$
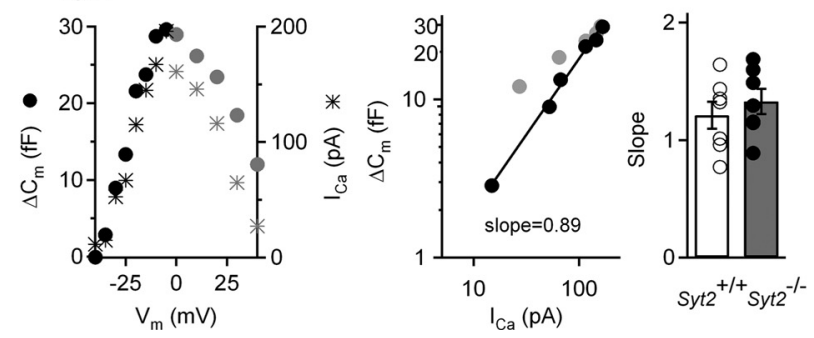

Figure 6. $\mathrm{Ca}^{2+}$-evoked exocytosis in $\mathrm{HHC}$ from $\mathrm{P} 15-\mathrm{P} 17$ Syt2 ${ }^{-/-}$mice. $\boldsymbol{A}$, Examples of $\mathrm{Ca}^{2+}$-evoked exocytosis in P15-P17 Syt2 ${ }^{+/+}$and Syt2 $2^{-1-} \mathrm{IHCs}$. Cells were stimulated by a $100 \mathrm{~ms}$ voltage step from a holding potential of -90 to $-10 \mathrm{mV}$. $\boldsymbol{B}$, Bar graph of average and individual $I_{\text {Ca }}$ peak amplitudes and their corresponding $\Delta C_{m}$ values, for Syt $2^{+/+}(n=8)$ and Syt2 ${ }^{-1-}(n=15) \mathrm{IHCS}$. C, Kinetics of $\mathrm{Ca}^{2+}$-dependent exocytosis. $\Delta C_{\mathrm{m}}$ is plotted against stimulus duration for pulses to $-10 \mathrm{mV}$. Note that the Syt2 $2^{+/+}$and Syt2 $2^{-/-}$data points are overlaid in inset. $D$, Average cumulative $\Delta C_{m}$ responses from P15-P17 Syt2 ${ }^{+/+}$and Syt2 ${ }^{-1-}$ IHCs elicited by $50 \mathrm{~ms}$ repetitive voltage steps to $-10 \mathrm{mV}$ (interstep interval of $100 \mathrm{~ms}$ ). $\boldsymbol{E}$, Left, $\Delta C_{\mathrm{m}}$ and $I_{\text {Ca }}$ peak amplitude for an IHC from a P16 Syt2 $2^{-1-}$ mouse, plotted for different voltages following a $100 \mathrm{~ms}$ voltage step from a holding potential of $-90 \mathrm{mV}$. Gray points indicate voltages beyond the $I_{\mathrm{Ca}_{\mathrm{P}}}$ peak which were not taken into account to calculate the $\Delta C_{\mathrm{m}}$ $I_{\text {Ca }}$ slope. Middle, Corresponding $\Delta C_{\mathrm{m}}$ versus $I_{\text {Ca }}$ plot. The logarithmized data were fitted by a line, giving a slope of 0.89 . Right, Average and individual slope values for P15-P17 Syt2 ${ }^{+/+}$ $(n=7)$ and Syt $2^{-1-}(n=6) \mathrm{IHCS}$.

observed in IHCs from P2-P3 Syt $2^{-/-}$mice, indicating that the RRP was rapidly refilled between voltage pulses (Fig. 5D).

Since Syt 2 has been recently proposed to underlie the $\mathrm{Ca}^{2+}$ dependence of vesicle release in mature IHCs (Johnson et al., 2010), we also investigated the properties of exocytosis in nearmature, P15-P17 IHCs from Syt $2^{-/-}$mice (Fig. 6). Again, we did not detect any obvious exocytotic defect. In Syt2 ${ }^{-/-}$P15-P17 IHCs, $100 \mathrm{~ms}$ voltage steps to $I_{\mathrm{Ca}}$ peak evoked $\Delta C_{\mathrm{m}}$ with a mean amplitude of $27.1 \pm 2.3 \mathrm{fF}$ for $I_{\mathrm{Ca}}$ peak of $183 \pm 11 \mathrm{pA}(n=15)$. These values were similar to those obtained in the wild-type littermates $[27.4 \pm 4.7 \mathrm{fF}$ and $182 \pm 23 \mathrm{pA}, n=8(p>0.5$ for both comparisons)]. In P15-P17 IHCs from Syt $2^{-/-}$mice, both the kinetics of exocytosis (Fig. 6C) and vesicle recruitment (Fig. 6D) were similar to those in the control littermates. Furthermore, the 
synaptic transfer function showed similar linear relationships in P15-P17 wild-type and Syt $2^{-/-}$mice (Fig. 6E).

In $S y t 7^{-/-}$mice, we did not find any defect of $\mathrm{Ca}^{2+}$-evoked exocytosis (RRP component) induced by $I_{\mathrm{Ca}}$ activation in immature (P2-P8) or post-hearing onset (P15-P30) IHCs (Table 1, Fig. 7). In these mice, $\mathrm{Ca}^{2+}$-evoked exocytosis underwent a normal postnatal maturation, with an increase in $\mathrm{Ca}^{2+}$ efficiency and a linearization of its $\mathrm{Ca}^{2+}$ dependency after hearing onset. A train of short depolarizations was also able to induce sustained vesicular release, which is indicative of a normal RRP refilling (data not shown).

\section{Discussion}

The here uncovered switch from an otoferlin-independent to an otoferlindependent exocytosis, reveals an as yet unknown maturation step of the IHC synapse that takes place around $\mathrm{P} 4$ in the mouse. At this developmental transition, the spontaneous $\mathrm{Ca}^{2+}$-driven spiking activity of IHCs rises to its highest frequency (Marcotti et al., 2003), and is generated both intrinsically and extrinsically through ATP-dependent excitation of IHCs (Tritsch and Bergles, 2010). The rise in IHC spike frequency and resulting increase in glutamate release, are supposed to be important for IHC synaptic maturation (Seal et al., 2008) and for proper mat(Rubel and Fritzsch, 2002; Leake et al., 2006; Leao et al., 2006). Notably, this period of postnatal cochlear development corresponds to an intense period of synaptic reorganization, refinement and retraction of type I and type II afferent neurites contacting IHCs (Lenoir et al., 1980; Huang et al., 2007). Our results show that before P4, immature IHCs make use of other $\mathrm{Ca}^{2+}$ sensors than otoferlin to drive $\mathrm{Ca}^{2+}$-dependent exocytosis. In that respect, it is noteworthy that a $\Delta C_{\mathrm{m}}$ response has been recorded in IHCs from hypothyroid rats, in which otoferlin could not be detected (Brandt et al., 2007; Sendin et al., 2007). The otoferlin-independent exocytosis phase reported here may account for this observation. Indeed, it has been shown that the maturation of the auditory neuroepithelium is delayed in thyroid hormone-deficient mice (Sendin et al., 2007).

Before P3, a period during which IHC exocytosis is otoferlinindependent, Syt1, Syt 2 or Syt7 were found to be dispensable for vesicle fusion, indicating that other, as yet unknown $\mathrm{Ca}^{2+}$ sensors, are involved in IHCs. Interestingly, we found that in response to repetitive stimulation, IHC exocytosis was seriously affected in Syt $1^{-1-}$ mice, suggesting that Syt1 is involved in the recruitment of synaptic vesicles to the RRP, possibly by ensuring fast $\mathrm{Ca}^{2+}$-dependent vesicle replenishment of the ribbon synapse. In CNS nerve terminals, Syt1 is also known to regulate the rate of endocytosis of synaptic vesicles that have undergone fusion (Poskanzer et al., 2003; Nicholson-Tomishima and Ryan, 2004). The replenishment defect of the RRP observed in Syt1 ${ }^{-/-}$ IHCs could therefore result from an impaired clearance of recently exocytosed vesicles from release sites (Hosoi et al., 2009).

The absence of Syt1 immunolabeling in IHCs after the onset of hearing, however, suggests that this $\mathrm{Ca}^{2+}$ sensor is not inuration of the central auditory pathway
Table 1. $\mathrm{Ca}^{2+}$-dependent exocytosis is not affected in Syt7 $7^{-/}$IHCs

\begin{tabular}{llcll}
\hline & \multicolumn{3}{l}{ RRP component } & \\
\cline { 2 - 5 } Age & Genotype & $\Delta C_{\mathrm{m}(\max )}(\mathrm{fF})$ & $\Delta C_{\mathrm{m}} / /_{\mathrm{Ca}}\left(\mathrm{fF} \mathrm{pA}^{-1}\right)$ & $\begin{array}{l}\mathrm{Ca}^{2+} \text { dependency } \\
N \text { power }\end{array}$ \\
\hline P2-P3 & Syt7 $^{+/+}$ & $12.5 \pm 1.9(n=3)$ & $0.13 \pm 0.02(n=3)$ & - \\
& Syt7 $^{-/-}$ & $11 \pm 0.2(n=3)$ & $0.12 \pm 0.02(n=3)$ & $2.1 \pm 0.2(n=2)$ \\
P6-P8 & Syt7 $^{+/+}$ & $20 \pm 4(n=6)$ & $0.12 \pm 0.02(n=6)$ & $2.2 \pm 0.2(n=4)$ \\
& Syt7 $^{-/-}$ & $24.3 \pm 6(n=8)$ & $0.17 \pm 0.04(n=8)$ & $2.2 \pm 0.1(n=6)$ \\
P15-P30 & Syt7 $^{+/+}$ & $66 \pm 11(n=6)$ & $0.28 \pm 0.05(n=6)$ & $0.9 \pm 0.1(n=5)$ \\
& Syt7 $^{-/-}$ & $69 \pm 11(n=5)$ & $0.37 \pm 0.08(n=5)$ & $1.1 \pm 0.2(n=5)$ \\
\hline
\end{tabular}

Figure 7. Comparative $\mathrm{Ca}^{2+}$ thresholds triggering exocytosis in IHCs during postnatal development. $A$, Comparative IHC
B

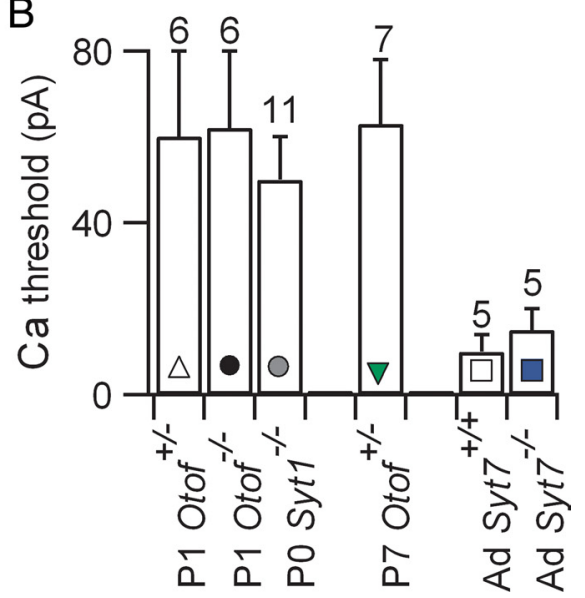

volved in mature IHCs. Furthermore, post-hearing-onset IHCs from $S y t 2^{-1-}$ or $S y t 7^{-1-}$ mice display normal exocytosis, indicating that Syt2 and Syt7 are also not essential for exocytosis in mature IHCs. This result is consistent with the absence of Syt 2 in IHCs beyond the first postnatal week. Since several Syt isoforms are expressed in immature IHCs, we cannot exclude at present that the lack of a strong phenotype in single Syt-null mice may be due to functional redundancy between Syts, although we note that a redundancy between Syt isoforms has not been shown so far in other synapses. Complexins, that are also known to bind to the SNARE complex and regulate fast exocytosis in conjunction with Syts in most neurosecretory synapses, are also dispensable at the mature IHC ribbon synapse (Strenzke et al., 2009). Together, these results suggest that the mature IHC makes use of an unconventional synaptic machinery, which includes otoferlin, to control exocytosis. The recent report of a temperature-sensitive form of deafness caused by an otoferlin mutation, that manifests a sudden hearing impairment provoked by fever in otherwise normal hearing children, further argues in favor of otoferlin playing a critical role at the synapses of mature IHCs (Marlin et al., 2010).

Surprisingly, exocytosis of P7 immature IHCs, while otoferlin-dependent, still showed a low $\mathrm{Ca}^{2+}$ efficiency compared with mature IHCs (Fig. 7). Indeed, the $\mathrm{Ca}^{2+}$ threshold (minimum $I_{\mathrm{Ca}}$ required to evoke a release of vesicles $>5 \mathrm{fF}$ ) was similar in P1 IHCs (otoferlin not required) and P7 IHCs (otoferlin required), while it is much lower in post-hearing onset (P15- 
P30), mature IHCs (Fig. 7). Likewise, the slopes of the synaptic transfer function were steep for all genotypes at P7 or younger $(N$ $\sim 2)$, while they were less steep $(N \sim 1)$ in P15-P30 wild-type mice (Fig. 7A). One might hypothesize that as yet undefined otoferlin partners (such as specific SNAREs, or other Syts) are lacking to set a linear, highly $\mathrm{Ca}^{2+}$-sensitive, synaptic function in P6 IHCs. Synaptotagmin 4, present in mature IHCs only, might be one of the otoferlin partners, since it has been shown to be required for the linearization of the synaptic transfer function (Johnson et al., 2010). A different distribution of $\mathrm{Ca}^{2+}$ channels at the synaptic active zones between immature and mature IHCs is also expected to change of the synaptic transfer function. In P6 $\mathrm{IHCs}, \mathrm{Ca}^{2+}$ channels are not exclusively located at the active zone (Zampini et al., 2010), and the extrasynaptic location of some $\mathrm{Ca}^{2+}$ channels may contribute to the lower " $\mathrm{Ca}^{2+}$ efficiency" of exocytosis in immature IHCs.

Otoferlin is a member of the ferlin protein family, which includes fer-1, dysferlin and myoferlin. When defective, dysferlin and myoferlin are responsible for muscular dystrophies (Bansal and Campbell, 2004). In Caenorhabditis elegans, Fer-1 is required for $\mathrm{Ca}^{2+}$-dependent vesicle fusion in spermatids during spermiogenesis (Achanzar and Ward, 1997; Washington and Ward, 2006). Based on the muscular phenotypes of the dysferlin and myoferlin knock-out mice, a role of these proteins in $\mathrm{Ca}^{2+}$. dependent membrane repair processes and myoblast membrane fusion, respectively, has been proposed (Bansal et al., 2003; Doherty et al., 2005). Otoferlin, whose C2 domains bind to SNARE proteins in a $\mathrm{Ca}^{2+}$-dependent manner (Roux et al., 2006), is critically involved in membrane vesicle fusion in IHCs from $\sim \mathrm{P} 4-\mathrm{P} 5$ onwards. In an in vitro fusion assay, otoferlin accelerates membrane fusion with higher $\mathrm{Ca}^{2+}$ affinity than Syt1 (C. Johnson and E. R. Chapman personal communication). In vestibular hair cells, otoferlin has been shown to be essential for a high affinity $\mathrm{Ca}^{2+}$ sensor function that allows fast exocytosis during brief cell depolarizations and low $\mathrm{Ca}^{2+}$ stimuli (Dulon et al., 2009). The requirement for otoferlin at the mature IHC synapse is likely due to a constraint specific to the auditory ribbon synapse organization, and/or its mode of exocytosis that involves multivesicular release (Glowatzki and Fuchs, 2002). It is possible that the larger number of C2 domains in otoferlin than in Syt1 (six vs two) enables more complex interactions between otoferlin and SNARE proteins, perhaps controlling the supply of vesicles to the release sites, as recently suggested in pachanga mice (Pangrsic et al., 2010) and/or allowing a variety of vesicle fusion modes. In the mature IHC, which does not contain Syt 1 or Syt2, the proportion of coordinated multivesicular fusion events at the ribbon synapse has been shown much higher than in Syts-expressing IHCs from pre-hearing animals (Grant et al., 2010). We thus suggest that otoferlin has a synchronizing effect on the multivesicular fusion events, an effect that could be attenuated by the coexistence of Syts, notably Syt 1 , in immature IHCs.

\section{References}

Achanzar WE, Ward S (1997) A nematode gene required for sperm vesicle fusion. J Cell Sci 110:1073-1081.

Bansal D, Campbell KP (2004) Dysferlin and the plasma membrane repair in muscular dystrophy. Trends Cell Biol 14:206-213.

Bansal D, Miyake K, Vogel SS, Groh S, Chen CC, Williamson R, McNeil PL, Campbell KP (2003) Defective membrane repair in dysferlin-deficient muscular dystrophy. Nature 423:168-172.

Beurg M, Safieddine S, Roux I, Bouleau Y, Petit C, Dulon D (2008) Calcium- and otoferlin-dependent exocytosis by immature outer hair cells. J Neurosci 28:1798-1803.

Beutner D, Moser T (2001) The presynaptic function of mouse cochlear inner hair cells during development of hearing. J Neurosci 21:4593-4599.
Beutner D, Voets T, Neher E, Moser T (2001) Calcium dependence of exocytosis and endocytosis at the cochlear inner hair cell afferent synapse. Neuron 29:681-690.

Brandt A, Striessnig J, Moser T (2003) CaV1.3 channels are essential for development and presynaptic activity of cochlear inner hair cells. J Neurosci 23:10832-10840.

Brandt A, Khimich D, Moser T (2005) Few CaV1.3 channels regulate the exocytosis of a synaptic vesicle at the hair cell ribbon synapse. J Neurosci 25:11577-11585.

Brandt N, Kuhn S, Münkner S, Braig C, Winter H, Blin N, Vonthein R, Knipper M, Engel J (2007) Thyroid hormone deficiency affects postnatal spiking activity and expression of $\mathrm{Ca}^{2+}$ and $\mathrm{K}^{+}$channels in rodent inner hair cells. J Neurosci 27:3174-3186.

Chapman ER (2008) How does synaptotagmin trigger neurotransmitter release? Annu Rev Biochem 77:615-641.

Doherty KR, Cave A, Davis DB, Delmonte AJ, Posey A, Earley JU, Hadhazy M, McNally EM (2005) Normal myoblast fusion requires myoferlin. Development 132:5565-5575.

Dulon D, Safieddine S, Jones SM, Petit C (2009) Otoferlin is critical for a highly sensitive and linear calcium-dependent exocytosis at vestibular hair cell ribbon synapses. J Neurosci 29:10474-10487.

Geppert M, Goda Y, Hammer RE, Li C, Rosahl TW, Stevens CF, Südhof TC (1994) Synaptotagmin I: a major $\mathrm{Ca}^{2+}$ sensor for transmitter release at a central synapse. Cell 79:717-727.

Gil-Loyzaga P, Pujol R (1988) Synaptophysin in the developing cochlea. Int J Dev Neurosci 6:155-160.

Glowatzki E, Fuchs PA (2002) Transmitter release at the hair cell ribbon synapse. Nat Neurosci 5:147-154.

Goutman JD, Glowatzki E (2007) Time course and calcium dependence of transmitter release at a single ribbon synapse. Proc Natl Acad Sci U S A 104:16341-16346.

Grant L, Yi E, Glowatzki E (2010) Two modes of release shape the postsynaptic response at the inner hair cell ribbon synapse. J Neurosci 30:4210-4220.

Hosoi N, Holt M, Sakaba T (2009) Calcium dependence of exo- and endocytotic coupling at a glutamatergic synapse. Neuron 63:216-229.

Huang LC, Thorne PR, Housley GD, Montgomery JM (2007) Spatiotemporal definition of neurite outgrowth, refinement and retraction in the developing mouse cochlea. Development 134:2925-2933.

Johnson SL, Marcotti W, Kros CJ (2005) Increase in efficiency and reduction in $\mathrm{Ca}^{2+}$ dependence of exocytosis during development of mouse inner hair cells. J Physiol 563:177-191.

Johnson SL, Franz C, Kuhn S, Furness DN, Rüttiger L, Münkner S, Rivolta MN, Seward EP, Herschman HR, Engel J, Knipper M, Marcotti W (2010) Synaptotagmin IV determines the linear $\mathrm{Ca}^{2+}$ dependence of vesicle fusion at auditory ribbon synapses. Nat Neurosci 13:45-52.

Jones TA, Leake PA, Snyder RL, Stakhovskaya O, Bonham B (2007) Spontaneous discharge patterns in cochlear spiral ganglion cells before the onset of hearing in cats. J Neurophysiol 98:1898-1908.

Keen EC, Hudspeth AJ (2006) Transfer characteristics of the hair cell's afferent synapse. Proc Natl Acad Sci U S A 103:5537-5542.

Kros CJ, Ruppersberg JP, Rüsch A (1998) Expression of a potassium current in inner hair cells during development of hearing in mice. Nature 394:281-284.

Leake PA, Hradek GT, Chair L, Snyder RL (2006) Neonatal deafness results in degraded topographic specificity of auditory nerve projections to the cochlear nucleus in cats. J Comp Neurol 497:13-31.

Leao RN, Sun H, Svahn K, Berntson A, Youssoufian M, Paolini AG, Fyffe RE, Walmsley B (2006) Topographic organization in the auditory brainstem of juvenile mice is disrupted in congenital deafness. J Physiol 571:563-578.

Lenoir M, Shnerson A, Pujol R (1980) Cochlear receptor development in the rat with emphasis on synaptogenesis. Anat Embryol (Berl) 160:253-262.

Lenzi D, Runyeon JW, Crum J, Ellisman MH, Roberts WM (1999) Synaptic vesicle populations in saccular hair cells reconstructed by electron tomography. J Neurosci 19:119-132.

Lindau M, Neher E (1988) Patch-clamp techniques for time-resolved capacitance measurements in single cells. Pflügers Arch 411:137-146.

Lippe WR (1994) Rhythmic spontaneous activity in the developing avian auditory system. J Neurosci 14:1486-1495.

Marcotti W, Johnson SL, Rusch A, Kros CJ (2003) Sodium and calcium 
currents shape action potentials in immature mouse inner hair cells. J Physiol 552:743-761.

Marlin S, Feldmann D, Nguyen Y, Rouillon I, Loundon N, Jonard L, Bonnet C, Couderc R, Garabedian EN, Petit C, Denoyelle F (2010) Temperature-sensitive auditory neuropathy associated with an otoferlin mutation: deafening fever! Biochem Biophys Res Commun 394:737-742.

Michalski N, Michel V, Bahloul A, Lefèvre G, Barral J, Yagi H, Chardenoux S, Weil D, Martin P, Hardelin JP, Sato M, Petit C (2007) Molecular characterization of the ankle-link complex in cochlear hair cells and its role in the hair bundle functioning. J Neurosci 27:6478-6488.

Moser T, Beutner D (2000) Kinetics of exocytosis and endocytosis at the cochlear inner hair cell afferent synapse of the mouse. Proc Natl Acad Sci U S A 97:883-888.

Nicholson-Tomishima K, Ryan TA (2004) Kinetic efficiency of endocytosis at mammalian CNS synapses requires synaptotagmin I. Proc Natl Acad Sci U S A 101:16648-16652.

Pang ZP, Sun J, Rizo J, Maximov A, Südhof TC (2006) Genetic analysis of synaptotagmin 2 in spontaneous and $\mathrm{Ca}^{2+}$-triggered neurotransmitter release. EMBO J 25:2039-2050.

Pangrsic T, Lasarow L, Reuter K, Takago H, Schwander M, Riedel D, Frank T, Tarantino LM, Bailey JS, Strenzke N, Brose N, Müller U, Reisinger E, Moser T (2010) Hearing requires otoferlin-dependent efficient replenishment of synaptic vesicles in hair cells. Nat Neurosci 7:869-876.

Poskanzer KE, Marek KW, Sweeney ST, Davis GW (2003) Synaptotagmin I is necessary for compensatory synaptic vesicle endocytosis in vivo. Nature 426:559-563.

Roux I, Safieddine S, Nouvian R, Grati M, Simmler MC, Bahloul A, Perfettini I, Le Gall M, Rostaing P, Hamard G, Triller A, Avan P, Moser T, Petit C (2006) Otoferlin, defective in a human deafness form, is essential for exocytosis at the auditory ribbon synapse. Cell 127:277-289.

Rubel EW, Fritzsch B (2002) Auditory system development: primary auditory neurons and their targets. Annu Rev Neurosci 25:51-101.

Safieddine S, Wenthold RJ (1999) SNARE complex at the ribbon synapses of cochlear hair cells: analysis of synaptic vesicle- and synaptic membraneassociated proteins. Eur J Neurosci 11:803-812.

Schneggenburger R, Neher E (2000) Intracellular calcium dependence of transmitter release rates at a fast central synapse. Nature 406:889-893.

Seal RP, Akil O, Yi E, Weber CM, Grant L, Yoo J, Clause A, Kandler K, Noebels
JL, Glowatzki E, Lustig LR, Edwards RH (2008) Sensorineural deafness and seizures in mice lacking vesicular glutamate transporter 3 . Neuron 57:263-275.

Sendin G, Bulankina AV, Riedel D, Moser T (2007) Maturation of ribbon synapses in hair cells is driven by thyroid hormone. J Neurosci 27:3163-3173.

Strenzke N, Chanda S, Kopp-Scheinpflug C, Khimich D, Reim K, Bulankina AV, Neef A, Wolf F, Brose N, Xu-Friedman MA, Moser T (2009) Complexin-I is required for high-fidelity transmission at the endbulb of Held auditory synapse. J Neurosci 29:7991-8004.

Südhof TC (2002) Synaptotagmins: why so many? J Biol Chem 277: 7629-7632.

Sun J, Pang ZP, Qin D, Fahim AT, Adachi R, Südhof TC (2007) A dual$\mathrm{Ca}^{2+}$-sensor model for neurotransmitter release in a central synapse. Nature 450:676-682.

Tritsch NX, Bergles DE (2010) Developmental regulation of spontaneous activity in the mammalian cochlea. J Neurosci 30:1539-1550.

Tritsch NX, Yi E, Gale JE, Glowatzki E, Bergles DE (2007) The origin of spontaneous activity in the developing auditory system. Nature 450: $50-55$.

von Poser C, Ichtchenko K, Shao X, Rizo J, Südhof TC (1997) The evolutionary pressure to inactivate. A subclass of synaptotagmins with an amino acid substitution that abolishes $\mathrm{Ca}^{2+}$ binding. J Biol Chem 272:14314-14319.

Washington NL, Ward S (2006) FER-1 regulates $\mathrm{Ca}^{2+}$-mediated membrane fusion during C. elegans spermatogenesis. J Cell Sci 119:2552-2562.

Wölfel M, Schneggenburger R (2003) Presynaptic capacitance measurements and $\mathrm{Ca}^{2+}$ uncaging reveal submillisecond exocytosis kinetics and characterize the $\mathrm{Ca}^{2+}$ sensitivity of vesicle pool depletion at a fast CNS synapse. J Neurosci 23:7059-7068.

Yasunaga S, Grati M, Cohen-Salmon M, El-Amraoui A, Mustapha M, Salem N, El-Zir E, Loiselet J, Petit C (1999) A mutation in OTOF, encoding otoferlin, a FER-1-like protein, causes DFNB9, a nonsyndromic form of deafness. Nat Genet 21:363-369.

Zampini V, Johnson SL, Franz C, Lawrence ND, Münkner S, Engel J, Knipper M, Magistretti J, Masetto S, Marcotti W (2010) Elementary properties of $\mathrm{CaV} 1.3 \mathrm{Ca}^{2+}$ channels expressed in mouse cochlear inner hair cells. J Physiol 588:187-199. 